\title{
5. CENOZOIC RADIOLARIANS FROM OCEAN DRILLING PROGRAM LEG 101, BAHAMAS (SITES 627 AND 628) AND SURROUNDING REGION1
}

\author{
Amanda A. Palmer ${ }^{2}$
}

\begin{abstract}
Radiolarians from two sites north of Little Bahama Bank (Sites 627 and 628) are correlated with assemblages from sites on the southeastern U.S. coastal plain and continental shelf and from DSDP Sites 391 and 534 in the Blake-Bahama Basin. Results show that deposition of biogenic silica-rich sediments occurred in this region from the late Oligocene through middle Miocene, although the record is interrupted by unconformities. Radiolarians help constrain the age of a mass-transported deposit at Site 627 that appears to be coeval with the Great Abaco Member of the Blake Ridge Formation.
\end{abstract}

\section{INTRODUCTION}

Radiolarians occur at only two sites on the Little Bahama Bank transect occupied during Leg 101, yet provide valuable information about regional Oligocene-Miocene depositional history when considered with results from nearby sites. In addition to examining material from Sites 627 and 628 (see Table 1), samples were examined from South Carolina coastal plain localities (Coosawhatchie Clay Member of the Hawthorn Formation; Abbott and Andrews, 1979); AMCOR 6002 (Southeast Georgia Embayment; Hathaway et al., 1976); and DSDP Site 534 (Blake Bahama Basin; Sheridan, Gradstein, et al., 1983). Published data from DSDP Site 391 (Benson, Sheridan, et al., 1978; Weaver and Dinkelman, 1978) also were correlated with the Little Bahama Bank sites.

Site 634 (Northeast Providence Channel, Bahamas) reoccupied the location of DSDP Site 98, from which a radiolarianbearing Cenozoic sequence was recovered (Hollister, Ewing, et al., 1972). Unfortunately, the upper $144 \mathrm{~m}$ of Site 634 was washed in an attempt to reach the Upper Cretaceous target zone within the time remaining for the cruise. No samples examined from this site contained radiolarians. Because no radiolarian data from Site 98 have yet been published, material from that site was studied in place of the washed section at Hole 634A. These results appear separately in a short note (Palmer, this volume).

\section{METHODS OF INVESTIGATION}

Ten- $\mathrm{cm}^{3}$ samples were selected from siliceous intervals at Sites 627 , 628 , and 534; one sample per section was obtained from AMCOR 6002 ; two or more samples were taken at each coastal plain locality. Conventional radiolarian preparation procedures were followed (Riedel and Sanfilippo, 1977), including disaggregation of the sample in hydrogen peroxide solution, treatment with hydrochloric acid to remove calcium carbonate, and sieving through a $63-\mu \mathrm{m}$ mesh screen. An ultrasonic probe was used to disaggregate highly indurated samples from Site 534 when conventional procedures failed.

Strewn slides of the residue were made for each sample and scanned for diagnostic taxa at $250 \times$. Zones were identified using the standard low-latitude radiolarian zonation of Riedel and Sanfilippo (1978).

\section{SITE 627}

Site 627 (1028 m water depth) is the basinward site of the Leg 101 Little Bahama Bank transect (see Table 1; Fig. 1).

\footnotetext{
${ }^{1}$ Austin, J. A., Jr., Schlager, W., et al., Proc. ODP, Sci. Results, 101: College Station, TX (Ocean Drilling Program).

2 Ocean Drilling Program, Texas A\&M University, College Station, TX 77843.
}

Twenty samples were recovered for studying radiolarians from the clay-rich intervals of Hole 627B (Table 2). Half of these came from Cores 101-627B-18X and 101-627B-19X (Fig. 2) and contained few-to-common radiolarians, along with abundant siliceous sponge spicules. The other samples proved to be barren of radiolarians, except for Sample 101-627B-12H-5, 62-64 cm, which contained several nondiagnostic taxa. A few radiolarians were observed in thin sections of chert pebbles from Core 101627B-21X. The occurrence of Phormocyrtis suggests an early to middle Eocene age for this chert.

Sample 101-627B-18X-1, 60-62 cm, from unlithified foraminiferal packstone, contains sparse, moderately preserved radiolarians. Diagnostic species are rare and include Stichocorys wolffii, Stichocorys delmontensis, and Didymocyrtis mammifera. These species indicate the upper Calocycletta costata to lower Dorcadospyris alata zones of latest early to earliest middle Miocene age, respectively.

Nine samples were recovered from the lithologically heterogeneous Core 101-627B-19X. The upper six samples are from green clay intraclasts from the unlithified floatstone in the upper part of the core, above $50 \mathrm{~cm}$ in Section 101-627B-19X-6. The remaining three samples are from the firm nannofossil ooze in the lower part of the core. Radiolarians and siliceous sponge spicules are more abundant in the ooze than in the floatstone clasts.

The six samples from Sections 101-627B-19X-1 through $-627 \mathrm{~B}-19 \mathrm{X}-5$ are from mud clasts in the floatstone. Age assignments obtained from these clasts do not necessarily apply to the matrix. The appearance of Stichocorys delmontensis in Sample 101-627B-19X-5, 20-22 cm, suggests the Stichocorys delmon-

Table 1. Location of sites discussed.

\begin{tabular}{lrrr}
\hline & Latitude & Longitude & $\begin{array}{r}\text { Water } \\
\text { depth } \\
\text { (corr.; in m) }\end{array}$ \\
\hline 627 & $27^{\circ} 38.10^{\prime} \mathrm{N}$ & $78^{\circ} 17.65^{\prime} \mathrm{W}$ & 1028 \\
628 & $27^{\circ} 31.85^{\prime} \mathrm{N}$ & $78^{\circ} 18.95^{\prime} \mathrm{W}$ & 966 \\
634 & $25^{\circ} 23.02^{\prime} \mathrm{N}$ & $77^{\circ} 18.88^{\prime} \mathrm{W}$ & 2835 \\
391 & $28^{\circ} 13.61^{\prime} \mathrm{N}$ & $75^{\circ} 00.00^{\prime} \mathrm{W}$ & 4974 \\
534 & $28^{\circ} 20.60^{\prime} \mathrm{N}$ & $75^{\circ} 22.90^{\prime} \mathrm{W}$ & 4971 \\
AMCOR 6002 & $31^{\circ} 08.57^{\prime} \mathrm{N}$ & $80^{\circ} 31.05^{\prime} \mathrm{W}$ & 32 \\
Dawson's Landing Outcrop, Jasper County, South Carolina \\
\multicolumn{3}{c}{ (Abbott and Andrews, 1979). } \\
Auger Hole near Dawson's Landing, Jasper County, South \\
Carolina (S. D. Heron, pers. comm., 1984). \\
Pengree Prospect Pit, Beaufort County, South Carolina \\
\multicolumn{3}{c}{ (S. D. Heron, pers. comm., 1984). } \\
\hline
\end{tabular}




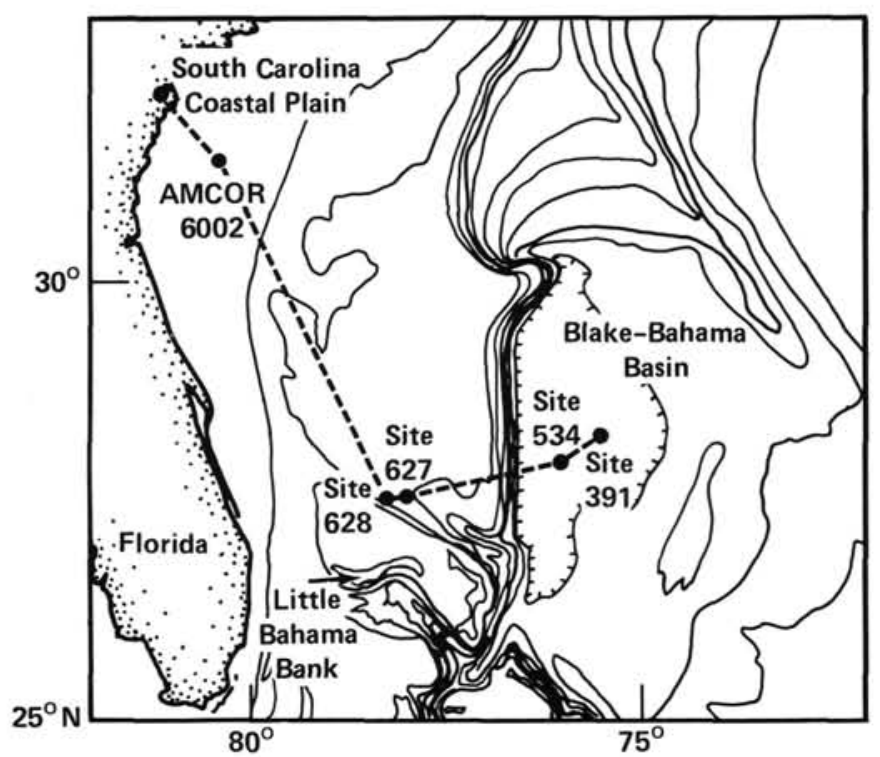

Figure 1. Location map of sites discussed. Dashed line indicates the transect of sites from the southeastern margin of the United States (South Carolina coastal plain and AMCOR 6002) past Little Bahama Bank (Sites 627 and 628) to the Blake-Bahama Basin (Sites 391 and 534).

tensis Zone. This is supported by the occurrence of Dorcadospyris ateuchus, which has its last appearance near the top of the $S$. delmontensis Zone. However, Liriospyris stauropora also occurs, and this species first appears near the base of the overlying Stichocorys wolffii Zone. Stichocorys wolffii occurs in Sample 101-627B-19X-2, 46-48 cm. This may indicate that clasts in Sections 1 and 2 of Core 101-627B-19X represent the lower $S$. wolffii Zone, while those in Sections 3 through 5 may represent the upper $S$. delmontensis Zone. Other species that occur in the mud clast samples and that indicate these zones are Cyrtocapsella cornuta, Cyrtocapsella tetrapera, Theocorys spongoconum, Carpocanopsis cingulata, Eucyrtidium diaphanes, Didymocyrtis prismatica (Plate 1, Fig. 4), and Carpocanopsis favosa.

The floatstones in Core 101-627B-19X (Fig. 2) and overlying cores appear to be coeval with debris flows of the Great Abaco Member (Blake Ridge Formation), first recovered at DSDP Site 391 in the Blake-Bahama Basin (Benson, Sheridan, et al., 1978; Jansa et al., 1979). Weaver and Dinkelman (1978) found slumped material of the $S$. wolffii and $S$. delmontensis zones in an interval having a $C$. costata Zone age at Site 391. Jansa et al. (1979) indicated that the Great Abaco Member may occur in the lower through upper Miocene section in the Blake-Bahama region.

Samples 101-627B-19X, CC, 101-627B-19X-7, 20-22 cm, and 101-627B-19X-6, 60-62 cm (from the firm ooze), are assigned to the Cyrtocapsella tetrapera Zone of early Miocene age, based on the presence of $C$. tetrapera (whose first occurrence defines the base of the zone) and the absence of Stichocorys delmontensis (whose first occurrence defines the base of the overlying Stichocorys delmontensis Zone). Calocycletta serrata (Plate 1, Fig. 3 ), a species restricted to the lower part of the C. tetrapera Zone, occurs in these samples and suggests that they represent only the lower part of the zone. Other species that support this age assignment are Didymocyrtis prismatica (Plate 1, Fig. 4), Cyclampterium pegetrum, Calocycletta virginis, Calocycletta robusta, Tepka perforata, Cyrtocapsella cornuta, Dorcadospyris ateuchus, Eurcyrtidium diaphanes, Theocorys spongoconum, Dorcadospyris simplex, and Carpocanopsis favosa.

\section{SITE 628}

Site 628, the middle site of the Little Bahama Bank transect, was drilled in $966 \mathrm{~m}$ of water (Table 1; Fig. 1). Samples for radiolarian study were selected from the fine-grained, calcareous ooze and clay-rich intervals of Cores 101-628A-14H through 101-628A-29X (Table 3). Only Cores 101-628A-14H through 101-628A-19H contained radiolarians (Fig. 3). Siliceous sponge spicules dominated these samples (a detailed report about these sponge spicules appears in Palmer, this volume).

Neogene radiolarians occur in Cores 101-628A-14H and 101628A-15H. Didymocyrtis mammifera and Calocycletta costata suggest the upper part of the Calocycletta costata Zone or the lower part of the Dorcadospyris alata Zone. Additional forms that support this age are Cyrtocapsella cornuta, tholoniids (a family that occurs only in the Neogene), and digitate orosphaerid spines, which are restricted to the middle Miocene (Friend and Riedel, 1967).

Samples from Cores 101-628A-16H through 101-628A-19H contain abundant siliceous objects in the form of branches, spines, and meshworks (Plate 1, Fig. 6); these are probably fragments and spines of orosphaerid radiolarians (F. M. Maurrasse, pers. comm., 1987), although at least some objects may be sponge debris (Palmer, this volume). Sponge fragments usually have a hollow axial canal that can be used to distinguish them from radiolarian fragments; these canals are sometimes (but not

Table 2. Occurrence of radiolarians in Hole 627B.

\begin{tabular}{|c|c|c|c|c|c|c|c|c|c|c|c|c|c|c|c|c|c|c|c|c|}
\hline Sample $(\mathrm{cm})$ & 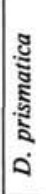 & 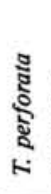 & 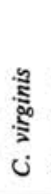 & 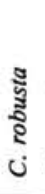 & $\begin{array}{l}\text { ปีँ } \\
\text { บे } \\
ن\end{array}$ & 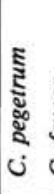 & $\begin{array}{l}\text { है } \\
\text { हैं }\end{array}$ & $\begin{array}{l}\text { डี } \\
\text { ปี } \\
\text { है } \\
ن\end{array}$ & 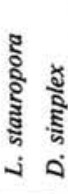 & 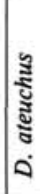 & 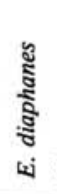 & 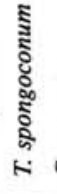 & 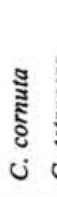 & 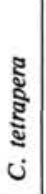 & 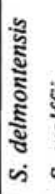 & 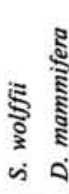 & \multicolumn{3}{|c|}{ Abundance } & Zone \\
\hline 627B-18X-1, 60-62 & - & - & - & - & - & - & - & - & -- & - & - & - & - & $\overline{0}$ & $R$ & $C \mathrm{R}$ & \multirow{8}{*}{\multicolumn{2}{|c|}{$*$}} & \multirow{8}{*}{${ }^{*}$} & lower $D$. alata to $C$. costata Zone \\
\hline $\begin{array}{l}\text { 627B-19X-1, 21-32 } \\
627 \mathrm{~B}-19 \mathrm{X}-1,122-124\end{array}$ & $\overline{\mathbf{R}}$ & $\bar{z}$ & $\overline{\mathrm{R}}$ & $\bar{z}$ & $z$ & - & $\bar{z}$ & $\bar{z}$ & $\pm=$ & - & $\bar{z}$ & $\bar{z}$. & $=$ & $\underline{R}$ & $\bar{R}$ & $\overline{-}=$ & & & & \\
\hline $627 \mathrm{~B}-19 \mathrm{X}-2,46-48$ & - & - & $\widehat{R}$ & - & - & - & $\mathrm{r}$ & - & -- & - & - & $\mathbf{R}$ & $\mathrm{F}$ & - & - & $\mathbf{R}$ & & & & (All samples are \\
\hline $627 \mathrm{~B}-19 \mathrm{X}-3,20-22$ & - & - & - & - & - & - & - & - & -- & - & - & $\mathbf{R}$ & - & - & - & - & & & & S. delmontensis Zone \\
\hline $627 \mathrm{~B}-19 \mathrm{X}-4,20-22$ & - & - & - & - & - & - & - & - & -- & R & $\mathbf{R}$ & $\mathrm{F}$ & C & $\mathbf{F}$ & - & -- & & & & \\
\hline $627 \mathrm{~B}-19 \mathrm{X}-5,20-22$ & - & - & - & - & - & - & - & $\mathrm{r}$ & $\mathrm{r}-$ & $\mathbf{R}$ & $\mathbf{R}$ & $\mathbf{R}$ & $\mathbf{R}$ & - & $\mathbf{R}$ & -- & & & & \\
\hline $\begin{array}{l}627 \mathrm{~B}-19 \mathrm{X}-6,60-62 \\
627 \mathrm{~B}-19 \mathrm{X}-7,20-22\end{array}$ & $\begin{array}{l}\mathbf{R} \\
\mathbf{R}\end{array}$ & $\begin{array}{l}\mathrm{R} \\
\mathrm{R}\end{array}$ & $\bar{z}$ & $\overline{-}$ & $\overline{\mathbf{F}}$ & $\overline{-}$ & $\underline{r}$ & $=-$ & $\begin{array}{ll}-\mathrm{r} \\
- & \mathrm{R}\end{array}$ & $\underline{F}$ & $\overline{\mathrm{R}}$ & $\stackrel{\mathrm{r}}{\mathrm{F}}$ & $\overline{\mathbf{F}}$ & $\begin{array}{l}\mathrm{F} \\
\mathrm{F}\end{array}$ & $\overline{-}$ & $\pm=$ & & & & \multirow{2}{*}{ C. tetrapera Zone } \\
\hline 627B-19X-CC, 20-22 & F & $\mathbf{R}$ & F & C & C & $\mathrm{r}$ & - & - & -- & $\mathbf{R}$ & $\mathrm{r}$ & - & R & $\mathbf{R}$ & - & - & & & & \\
\hline
\end{tabular}

Note: Relative abundance of individual species: $C=$ common $(>100$ specimens/slide); $F=$ frequent $(11-100 /$ slide $) ; R=$ rare $(3-10 /$ slide $) ; r=$ very rare

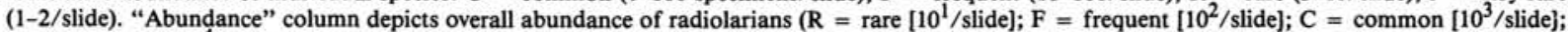
$\mathrm{A}=$ abundant $\left[10^{4} /\right.$ slide $]$ ). 
Rad Rad

Depth Sed. Abundance Preserv.

Core (mbsf) Lithology Struct. B R F C A B P M G

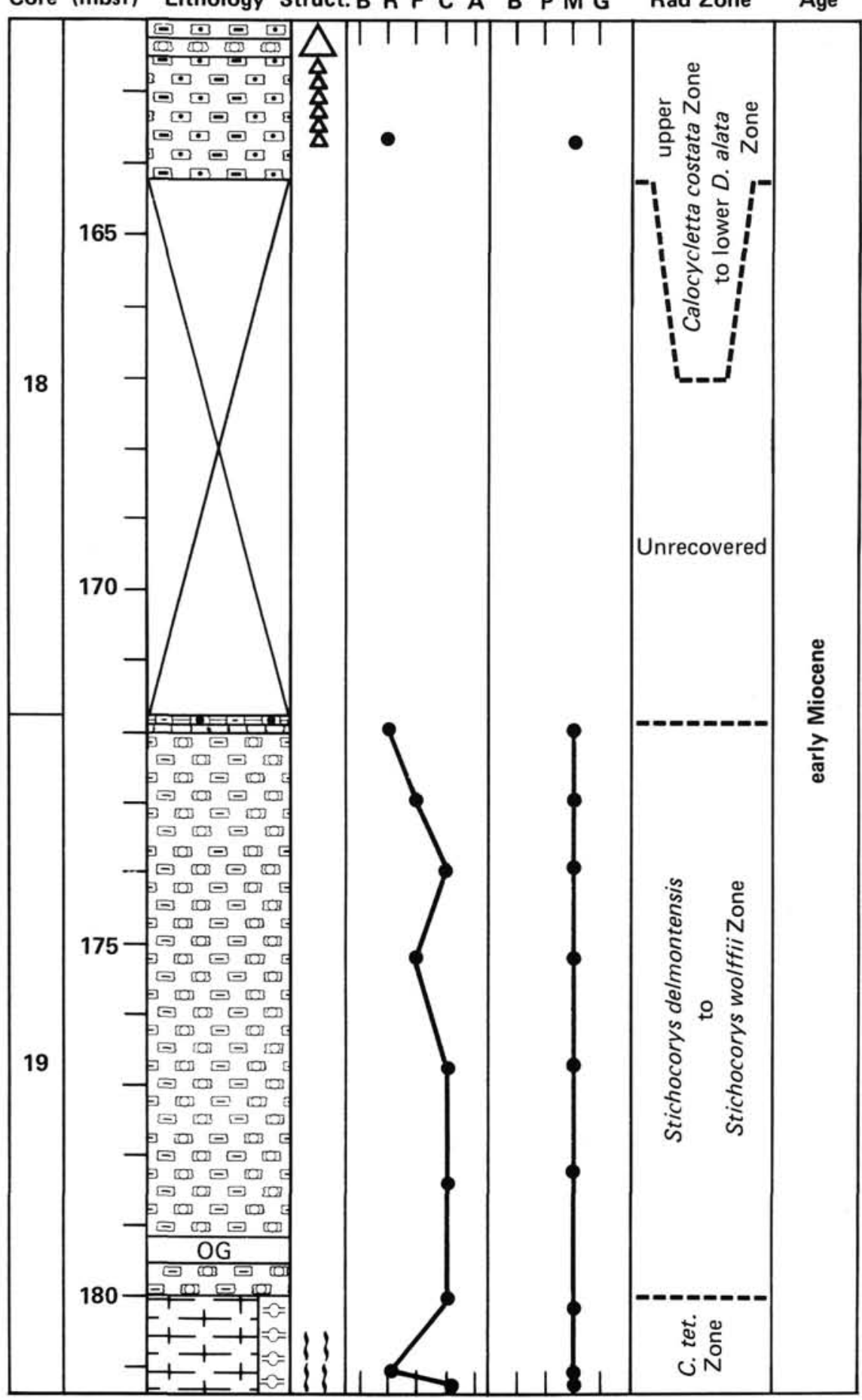

Figure 2. Results from Site 627, including sub-bottom depth (mbsf), lithology and sedimentary structures (see Palmer, Austin, and Schlager, 1986, for key to symbols), radiolarian abundance, radiolarian preservation, and radiolarian zones. $\mathrm{B}=$ barren; $\mathrm{R}=$ rare; $\mathrm{F}=$ frequent; $\mathrm{C}=\mathrm{com}$ mon; $\mathrm{A}=$ abundant; $\mathrm{P}=$ poor $\mathbf{M}=$ moderate; $\mathrm{G}=$ good.

consistently) visible in the questionable fragments from Hole $628 \mathrm{~A}$. Orosphaerid species tentatively identified on the basis of characteristic features observed in shell fragments and spines include Oradapis spongiosa, Orescena carolae, Orescena gegenbauri, and Oropagis dolium. All these species are typical of the late Oligocene. Friend and Riedel (1967) noted that, in general, orosphaerids are more abundant in late Oligocene and early Miocene sediments than in other deposits. Apart from the questionable fragments, approximately $90 \%$ of the radiolarian fauna consists of Dorcadospyris spp. 
Table 3. Occurrence of radiolarians in Hole 628A.

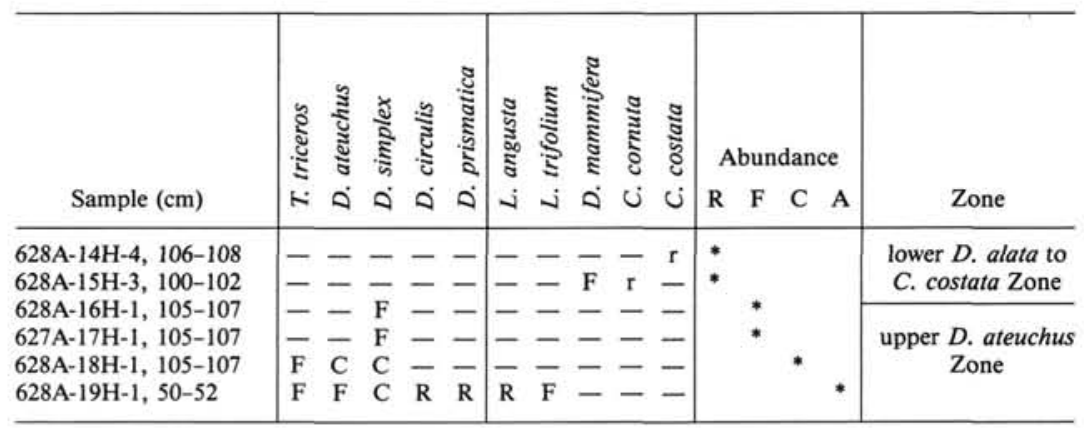

Note: Relative abundance of species and overall abundance of radiolarians same as noted in Table 2 footnote.

\section{Depth Sed. Abundance Preserv.}

Core (mbsf) Lithology Struct. B R F C A B P M G Rad Zone Age

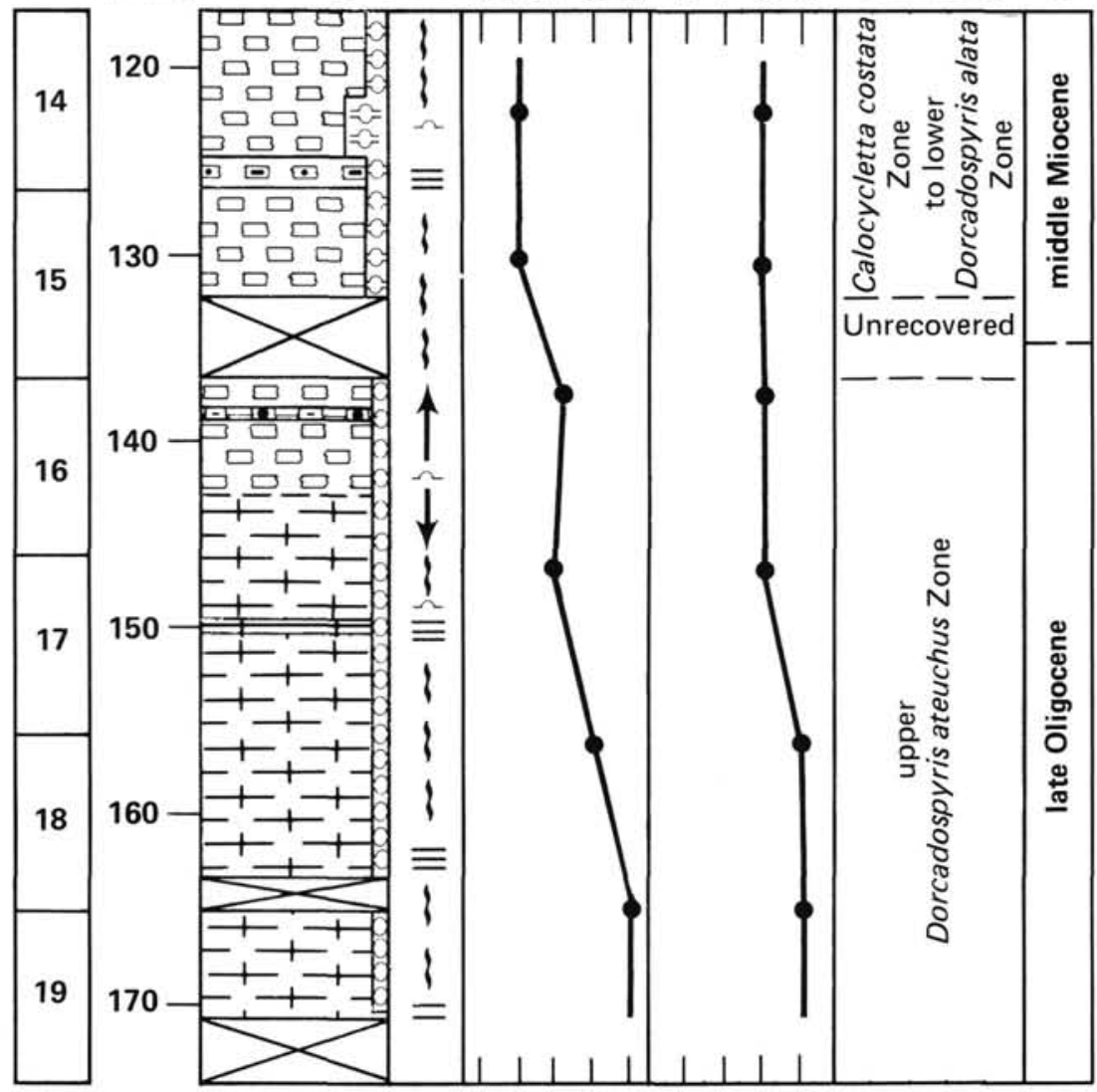

Figure 3. Results from Site 628 (see Fig. 2 for explanation).

The occurrence of Dorcadospyris ateuchus (Plate 2, Fig. 2) and the late form of Lithocyclia angusta (Plate 2, Fig. 3; Sanfilippo et al., 1985) in Cores 101-628A-18H and 101-628A-19H indicate the upper part of the Dorcadospyris ateuchus Zone of late Oligocene age. This age assignment is supported by the occurrence of Didymocyrtis prismatica (Plate 1, Fig. 5), Lychnocanoma trifolium, Tristylospyris triceros, Dorcadospyris simplex (Plate 2, Fig. 1), and Dorcadospyris circulis (Plate 2, Fig. 4).

\section{SITE 534}

Hole 534A (water depth of $4971 \mathrm{~m}$ ) was drilled in the BlakeBahama Basin during Leg 76 (Sheridan, Gradstein, et al., 1983;
Table 1; Fig. 1); no Cenozoic radiolarians were studied by the shipboard party. This site is important because the green siliceous mudstone found as radiolarian-bearing clasts at Site 627 occurs at Site 534 both as clasts and in situ. Forty-seven samples were obtained from Cores 76-534A-2 through 76-534A-7 and 76-534A-10 through 76-534A-20 from the siliceous mudstone and intraclastic chalk (containing siliceous mudstone clasts) lithologies; of these, 29 contained radiolarians (Table 4). The assemblage in the intraclastic chalk samples contained predominantly reworked middle Eocene radiolarians, as discussed next (and as indicated in Table 4).

Determining radiolarian ages was often difficult using samples from Hole 534A because extraction of radiolarians from 


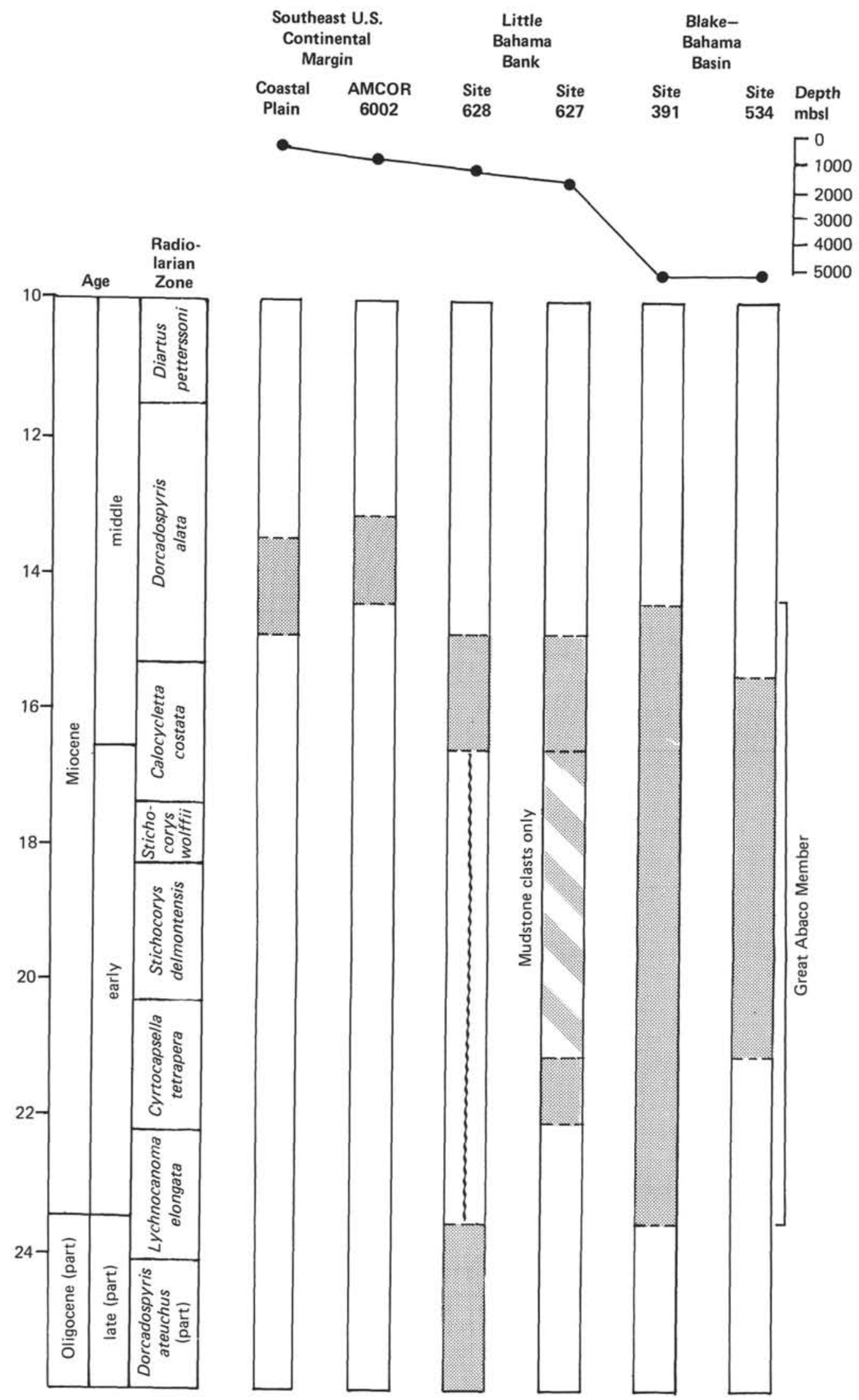

Figure 4. Occurrence of radiolarians in a transect from the southeastern margin of the United States (coastal plain) to Little Bahama Bank and from Little Bahama Bank to the Blake-Bahama Basin (location of sites shown in Fig. 1). Shaded intervals represent radiolarian zones recognized at each site. Radiolarian data from Site 391 are from Weaver and Dinkelman (1978). Absolute ages of radiolarian zones are based on the Berggren et al. (1985) time scale and correlation of radiolarian zones to that time scale by Barron et al. (1985). 
Table 4. Occurrence of radiolarians in Hole 534A.

\begin{tabular}{|c|c|c|c|c|c|c|c|c|c|c|c|c|c|c|c|c|c|c|c|c|c|c|c|}
\hline Sample $(\mathrm{cm})$ & Lithology ${ }^{a}$ & $\begin{array}{l}\text { Rew, } \\
\text { Eoc. }\end{array}$ & 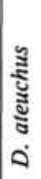 & 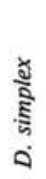 & 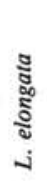 & 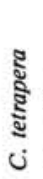 & 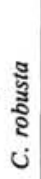 & 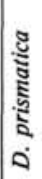 & 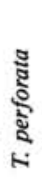 & 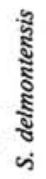 & ن & 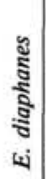 & 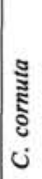 & $\begin{array}{l}\frac{y}{5} \\
\stackrel{5}{2} \\
ن\end{array}$ & $\begin{array}{l}\text { ป } \\
\text { : } \\
\text { : } \\
ن \\
ن\end{array}$ & 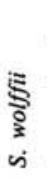 & 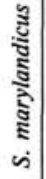 & 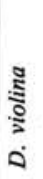 & $\frac{\Xi}{8}$ & 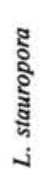 & 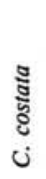 & 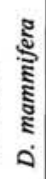 & Zone \\
\hline $\begin{array}{l}534 \mathrm{~A}-2-1,120-122 \\
534 \mathrm{~A}-4-2,80-82\end{array}$ & $\begin{array}{l}\text { siliceous mudstone } \\
\text { siliceous silty clay }\end{array}$ & & - & - & - & $\bar{R}$ & - & - & $\bar{R}$ & $\begin{array}{l}\mathrm{F} \\
\mathrm{C}\end{array}$ & - & - & $\bar{F}$ & $\begin{array}{l}\mathrm{R} \\
\mathrm{F}\end{array}$ & $\bar{r}$ & $\begin{array}{l}\mathbf{F} \\
\mathbf{C}\end{array}$ & - & $\frac{-}{r}$ & $\bar{r}$ & $\frac{-}{-}$ & $\begin{array}{l}\mathrm{R} \\
\mathrm{F}\end{array}$ & $\frac{r}{-}$ & $\begin{array}{l}\text { C. costata } \\
\text { Zone }\end{array}$ \\
\hline $534 \mathrm{~A}-4-3,96-98$ & siliceous silty clay & & - & - & - & $\mathbf{R}$ & $\mathbf{R}$ & - & $\mathbf{R}$ & $\mathrm{F}$ & - & - & - & $\mathbf{R}$ & - & $\mathrm{F}$ & - & $r$ & - & - & - & - & \\
\hline $534 \mathrm{~A}-4-4,60-62$ & siliceous silty clay & & - & $r$ & - & $\mathrm{F}$ & - & - & - & $\mathrm{F}$ & - & - & - & $\mathrm{R}$ & - & $\mathrm{F}$ & - & $\mathrm{r}$ & - & $\mathrm{r}$ & - & - & \\
\hline $534 \mathrm{~A}-4-5,24-30$ & siliceous silty clay & & - & - & - & - & - & - & r & - & - & - & - & - & - & - & - & - & $\mathbf{R}$ & - & - & - & \\
\hline $534 A-5-2,60-62$ & calcareous silty claystone & & - & - & - & - & $r$ & - & - & F & - & - & - & $\mathbf{R}$ & - & $\mathbf{F}$ & - & $\mathbf{r}$ & - & - & - & - & \\
\hline $534 \mathrm{~A}-5-3,91-93$ & calcareous silty claystone & & - & $\mathbf{R}$ & - & - & - & - & - & $\mathrm{F}$ & - & - & - & - & - & $\mathrm{F}$ & - & - & - & - & - & - & \\
\hline $534 A-6-1,80-82$ & intraclast. chalk w/silic. mud clasts & * & - & - & - & $\mathbf{R}$ & r & - & - & - & - & - & - & $\mathbf{R}$ & - & $\mathbf{R}$ & - & - & - & - & - & - & . wolffii \\
\hline $534 \mathrm{~A}-6-2,80-82$ & intraclast. chalk w/silic. mud clasts & - & - & $r$ & - & - & $\mathrm{F}$ & $r$ & - & $\mathbf{R}$ & - & $\mathrm{r}$ & - & $\mathbf{R}$ & $r$ & $\mathbf{R}$ & $\mathbf{r}$ & - & r & $\mathbf{r}$ & - & - & \\
\hline $534 \mathrm{~A}-6-3,80-82$ & intraclast. chalk w/silic. mud clasts & * & - & $\mathrm{r}$ & - & - & - & - & - & - & - & - & - & - & - & - & - & - & - & - & - & - & \\
\hline $534 A-7-1,104-106$ & siliceous mudstone & & - & - & - & $\mathbf{R}$ & - & - & - & $\mathbf{R}$ & - & - & - & $r$ & - & $\mathbf{R}$ & - & - & - & - & - & - & \\
\hline $534 \mathrm{~A}-7-3,74-76$ & siliceous mudstone & - & - & - & - & - & - & - & - & $\dddot{R}$ & - & $\mathbf{r}$ & - & $\mathbf{R}$ & - & $\mathbf{R}$ & r & - & - & - & - & - & \\
\hline $534 A-7-5,40-42$ & siliceous mudstone & - & - & $r$ & - & - & - & - & - & $r$ & - & - & - & $\mathrm{R}$ & $r$ & $\dddot{F}$ & - & - & $\mathbf{R}$ & - & - & - & \\
\hline $534 \mathrm{~A}-10-2,23-25$ & muddy porcellanite & & - & - & - & $r$ & - & - & $r$ & - & - & - & - & - & - & - & - & - & - & - & - & - & \\
\hline $534 \mathrm{~A}-11-2,52-54$ & diatomaceous silty claystone & & - & $r$ & - & $\mathbf{R}$ & $\mathbf{R}$ & - & - & $\mathbf{R}$ & - & - & - & $r$ & - & - & - & - & - & - & - & - & \\
\hline $534 \mathrm{~A}-11-3,28-30$ & diatomaceous silty claystone & & $r$ & - & $\mathbf{R}$ & $\mathbf{R}$ & $\mathbf{R}$ & - & $r$ & $\mathbf{R}$ & - & - & - & $r$ & $r$ & - & - & - & - & - & - & - & \\
\hline $534 \mathrm{~A}-12-2,97-99$ & siliceous claystone & & - & $\mathbf{R}$ & - & $\mathrm{F}$ & - & - & $\mathrm{r}$ & $\mathrm{F}$ & - & r & - & $\mathrm{R}$ & - & - & - & - & - & - & - & - & \\
\hline $534 \mathrm{~A}-12-4,60-62$ & siliceous mudstone $\mathrm{w} /$ mudstone chips & * & - & $\mathrm{r}$ & $\mathrm{r}$ & $\mathbf{R}$ & $\mathbf{r}$ & - & $\mathrm{r}$ & $\mathbf{R}$ & - & - & - & - & - & - & - & - & - & - & - & - & \\
\hline $534 \mathrm{~A}-12-5,60-62$ & siliceous mudstone $\mathrm{w} /$ mudstone chips & * & - & $\mathrm{r}$ & - & - & - & - & - & - & - & - & - & - & - & - & - & - & - & - & - & - & \\
\hline $534 \mathrm{~A}-13-1,78-80$ & siliceous mudstone $\mathrm{w} /$ mudstone chips & * & - & - & - & $\mathrm{r}$ & - & - & - & - & - & - & - & - & - & - & - & - & - & - & - & - & \\
\hline $534 \mathrm{~A}-13-2,45-47$ & debris flow & * & $\mathrm{r}$ & $\mathrm{r}$ & - & $\mathbf{F}$ & $\mathbf{R}$ & - & $r$ & $\mathbf{R}$ & - & - & - & - & - & - & - & - & - & - & - & - & S. delmontensis \\
\hline $534 \mathrm{~A}-13-3,28-30$ & debris flow & * & - & - & - & - & - & - & - & - & - & - & $\mathbf{R}$ & - & - & - & - & - & - & - & - & - & Zone \\
\hline $534 \mathrm{~A}-13-3,76-78$ & debris flow & * & - & - & - & - & $\mathbf{r}$ & - & - & - & - & - & - & - & - & - & - & - & - & - & - & - & \\
\hline $534 \mathrm{~A}-14-1,58-60$ & siliceous silty claystone & & - & $r$ & - & $\mathrm{F}$ & $\mathbf{R}$ & - & - & $\mathbf{R}$ & - & - & - & - & - & - & - & - & - & - & - & - & \\
\hline $534 \mathrm{~A}-14-2,86-88$ & siliceous silty claystone & & - & - & - & $\mathbf{R}$ & $\mathbf{R}$ & - & $\mathrm{r}$ & $\mathbf{r}$ & $\mathbf{r}$ & $\mathrm{r}$ & - & - & - & - & - & - & - & - & - & - & \\
\hline $534 \mathrm{~A}-14-3,98-100$ & siliceous silty claystone & & $r$ & $\mathbf{r}$ & - & $\mathbf{R}$ & - & - & - & $\mathbf{R}$ & - & - & - & - & - & - & - & - & - & - & - & - & \\
\hline $534 \mathrm{~A}-15-1,91-93$ & traclastic chalk (debris flow) & * & $\mathrm{r}$ & $\mathrm{r}$ & - & - & - & - & r & 一 & - & - & - & - & - & - & - & - & - & - & - & - & \\
\hline $534 \mathrm{~A}-16-1,91-93$ & intraclastic chalk (debris flow) & $*$ & $\mathbf{R}$ & $\mathbf{R}$ & $\mathbf{R}$ & - & $\mathbf{R}$ & r & $\mathrm{r}$ & - & - & - & - & - & - & - & - & - & - & - & - & - & \\
\hline $534 \mathrm{~A}-16-2,64-66$ & intraclastic chalk (debris flow) & - & $\mathrm{r}$ & $\mathrm{r}$ & - & r & $\mathrm{r}$ & - & - & - & - & - & - & - & - & - & - & - & - & - & - & - & \\
\hline
\end{tabular}

Note: Relative abundance same as in Table 2 footnote.

${ }^{a}$ Lithology is after Sheridan, Gradstein, et al. (1983).

b "Rew. Eoc." indicates presence of abundant reworked Eocene radiolarians.

the indurated claystones caused fragmentation without breaking down some of the clay. The intraclastic chalks contained predominantly reworked Eocene radiolarians and a few Miocene species.

As indicated in Table 4, Calocycletta costata (Plate 1, Fig. 1) appears in Samples 76-534A-2-1, 120-122 cm, and 76-534A-4-2, $80-82 \mathrm{~cm}$, indicating the Calocycletta costata Zone. The Stichocorys wolffii Zone extends from the first appearance of Stichocorys wolffii to the first appearance of $C$. costata. This zone is recognized in Samples 76-534A-4-3, 96-98 cm, through 76-534A$7-5,40-42 \mathrm{~cm}$. Spongasteriscus marylandicus (Plate 1, Fig. 2), a species found to be restricted to the $S$. wolffii Zone in the midAtlantic Coastal Plain by Palmer (1986), was observed in this interval. No samples were obtained from Cores 76-534A-8 and $-534 \mathrm{~A}-9$, because recovery of these calcareous lithologies was poor. Samples 76-534A-10-2, 23-25 cm, through 76-534A-16-2, 64-66 cm, were assigned to the Stichocorys delmontensis Zone as they occur between the first appearances of $S$. wolffii and $S$. delmontensis. No radiolarians were extracted from Cores 76534A-17 through -534A-20.

These results indicate that the age of the in-situ siliceous mudstone facies (as seen in Cores 76-534A-2 through 76-534A-5, 76-534A-7 through 76-534A-12-2, and 76-534A-14) is early Miocene (Calocycletta costata, Stichocorys wolffii, and Stichocorys delmontensis zones). This is equivalent in age to the mudstone clasts sampled at Site 627. The abundant, reworked, middle Eocene radiolarians in the intraclastic chalk and debris flows (Cores 76-534A-6, 76-534A-13-2 through 76-534A-13-3, and 76-534A15 through 76-534A-16) and in the siliceous mudstone having mudstone chips (as described in the core description of Leg 76; Sheridan, Gradstein, et al., 1983; Cores 76-534A-12-4 and 76534A-13-1) suggest that the mudstone clasts in these lithologies come (at least in part) from the widespread siliceous Eocene Bermuda Rise Formation (Jansa et al., 1979).

\section{AMCOR 6002}

Atlantic Margin Coring Project hole AMCOR 6002 (Table 1; Fig. 1) was drilled in the midshelf region ( $32 \mathrm{~m}$ water depth) of the Southeast Georgia Embayment in 1976 by the GLOMAR Conception, following procedures similar to those used on board the GLOMAR Challenger during the Deep Sea Drilling Project (Hathaway et al., 1976). A total of 33 rotary cores were recovered from Hole 6002; radiolarians occur in Cores 2 through 8. All samples contained radiolarians from the Dorcadospyris alata Zone, including Didymocyrtis laticonus, Stichocorys delmontensis, Lithopera renzae, Tepka perforata, and Liriospyris parkerae. The fauna is generally similar to that described by Weaver and Dinkelman (1978) from Cores 44-391A-5 through 44-391A-7; it appears to be slightly younger than the fauna in the early middle Miocene intervals identified at Sites 627 and 628 .

\section{SOUTH CAROLINA COASTAL PLAIN}

In addition to material from the offshore sites discussed previously, samples from the Coosawhatchie Clay Member (Hawthorn Formation) also were examined from the Dawson's Landing outcrop in Jasper County, South Carolina (Abbott and Andrews, 1979), from an auger hole nearby, and from the Pengree prospect pit in Beaufort County, South Carolina (S. D. Heron, pers. comm., 1984) (Fig. 1). The lithology observed in this outcrop was a smectite-rich diatomaceous mud having scattered porcellanite nodules. Diatoms are much more abundant than radiolarians, but Calocycletta costata, Didymocyrtis laticonus, and Lithopera renzae do occur, indicating the lower part of the Dorcadospyris alata Zone of middle Miocene age. 


\section{CORRELATION OF SITES}

The sites investigated here form a transect of the southeastern U.S. continental margin: from the coastal plain across Little Bahama Bank to the Blake-Bahama Basin (Fig. 1). Figure 4 shows the radiolarian zones recognized in the upper Oligocene through Miocene section along this transect (with absolute ages based on the Berggren et al., 1985, time scale and on correlation of radiolarian zones to that time scale by Barron et al., 1985). The presence of upper Oligocene to middle Miocene biosiliceous sediments in the Bahamas region indicates high biogenic silica productivity. However, because the sequence is interrupted by hiatuses, it is not clear whether this was a single continuous period of high productivity or several discontinuous intervals.

The late Oligocene and early Miocene record of silica production on the coastal plain and shelf is difficult to interpret because the record is discontinuous (interrupted by unconformities), and no known biogenic siliceous deposits occur. Much of the lower Miocene record is absent from the platform flanks as well, but a more complete record exists at the deeper basin sites (as downslope-transported material, in part). It appears that highly siliceous sediments were deposited throughout the southeastern part of the western North Atlantic Ocean in the early Miocene and early middle Miocene, although erosion removed much of the early Miocene record from the marginal areas (J. G. Baldauf and A. A. Palmer, unpubl. data). Episodes of topographically induced coastal upwelling associated with proto-Gulf Stream activity were suggested by Riggs (1984) as being responsible for the deposition of widespread phosphatic sediments in the Miocene of North Carolina; this activity may also have delivered nutrients that stimulated siliceous phytoplankton production along the southeastern margin of the United States. Upwelling conditions must have waned during the middle Miocene because nonsiliceous sediments (primarily calcareous) began to dominate in the region at that time.

\section{Debris Flows and Chalk Coeval with the Great Abaco Member}

Debris flows and intraclastic chalk recovered at Sites 627, 391, and 534 (Fig. 5) appear to be coeval with the Great Abaco Member of the Blake Ridge Formation (Jansa et al., 1979; Sheridan, Gradstein, et al., 1983; Bliefnick et al., 1983; Austin, Schlager, et al., 1986). In the model presented by Bliefnick et al. (1983), downslope transportation into the Blake-Bahama Basin occurred through several conduits during the Miocene, including the Great Abaco Canyon near Little Bahama Bank; material was removed from the flanks of Little Bahama Bank and redeposited in the Blake-Bahama Basin by mass transporting events. The debris flow with green radiolarian mudstone clasts in the upper part of Core 101-627B-19X appears to be an example of such transportation. The relatively large size of the clasts at Site 627 (up to several centimeters in diameter) may reflect a more proximal source than Cores 44-391A-8 and 44-391A-9 (Benson, Sheridan, et al., 1978), Cores 76-534A-3 through 76-534A-6, and 76-534A-15 through 76-534A-18 (Sheridan, Gradstein, et al., 1983). These contain smaller but lithologically similar clasts, suggesting sites more distal relative to the sources. The prevalence of reworked Eocene radiolarians suggests that some of the clasts in the intraclastic chalks at Site 534 were derived from an Eocene source, possibly the Bermuda Rise Formation or its equivalent. This may be evidence of multiple sources of transported materials to the Blake-Bahama Basin, which is also suggested by Bliefnick et al.'s model (1983).

\section{CONCLUSIONS}

Radiolarians were examined from samples recovered at Sites 627 and 628 (Little Bahama Bank) during Leg 101. Comparative material was obtained from sites on the southeastern conti- nental margin of the United States (South Carolina coastal plain and AMCOR Hole 6002) and from the Blake-Bahama Basin (Site 534; also data from published studies of Site 391).

These investigations further support earlier studies that radiolarians occur in the Bahamas region in the upper Oligocene through middle Miocene. Despite a discontinuous record owing to hiatuses and spot coring, silica deposition apparently ceased after the middle Miocene; only calcareous deposits occur after that time.

Debris flows and intraclastic chalk that show evidence of extensive subaqueous mass transportation were found on the flanks of Little Bahama Bank and in the Blake-Bahama Basin. These are equated to the Great Abaco Member of the Blake Ridge Formation (Benson, Sheridan, et al., 1978; Jansa, 1979; Austin, Schlager, et al., 1986). Radiolarian biostratigraphy indicates that siliceous mudstone of early Miocene age was eroded and redeposited throughout the early and early middle Miocene. Siliceous deposits of middle Eocene age (possibly the Bermuda Rise Formation or its equivalent) also contributed to the clasts, which indicates that more than one source of material contributed to the debris flows.

\section{ACKNOWLEDGMENTS}

I appreciate the assistance of the ODP Curatorial staff and the East Coast Repository in obtaining samples from DSDP Site 534. I obtained AMCOR samples through J. Hathaway (USGS); S. D. Heron (Duke University) provided samples from the South Carolina Coastal Plain. Peggy Myre (ODP) helped with sample preparation and photography; Frank Rack (ODP) also prepared samples. Artwork was drafted by Karen Benson and Jean Bettenhausen (ODP). I appreciate the thoughtfu reviews by J. A. Austin, Jr., D. A. Dunn, F. M. Maurrasse, and W. Schlager.

This is ODP Contribution ODP-P-87/121.

\section{REFERENCES}

Abbott, W. H., and Andrews, G. W., 1979. Middle Miocene marine diatoms from the Hawthorn Formation within Ridgeland Trough, South Carolina and Georgia. Micropaleontology, 25:225-271.

Austin, J. A., Jr., Schlager, W., et al., 1986. Proc. ODP, Initial Repts., 101: College Station, TX (Ocean Drilling Program).

Barron, J. A., Keller, G., and Dunn, D. A., 1985. A multiple microfossil biochronology for the Miocene. In Kennett, J. P. (Ed.), The Miocene Ocean: Geol. Soc. Am. Mem., 163:21-36.

Benson, W. E., and Sheridan, R. E., et al., 1978. Init. Repts. DSDP, 44: Washington (U.S. Govt. Printing Office).

Berggren, W. A., Kent, D. V., Flynn, J. J., and Van Couvering, J. A., 1985. Cenozoic Geochronology. Geol. Soc. Am. Bull., 96: 1407-1418.

Bliefnick, D. M., Robertson, A.H.F., and Sheridan, R. E., 1983. Deposition and provenance of Miocene intraclastic chalks, Blake-Bahama basin, western North Atlantic. In Sheridan, R. E., Gradstein, F. M., et al., Init. Repts. DSDP, 76: Washington (U.S. Govt. Printing Office), 727-748.

Campbell, A. S., and Clark, B. L., 1944. Miocene radiolarian faunas from southern California. Geol. Soc. Am. Spec. Pap., 51:1-76.

Carnevale, P., 1908. Radiolarie e silicoflagellati di Bergonzano (Reggio Emilia). R. Inst. Veneto Sci. Lett. Arti, Mem., 28:1-46.

Ehrenberg, C. G., 1873. Grossere Felsproben des Polycytinen-Mergel von Barbados mit weiteren Erlauterungen. Königliche Preussischen Akad. Wissenschaften, Berlin, Monatsber., Jahre 1873:213-263. 1875. Fortsetzung der mikrogeologischen Studien als Gesammt-Uebersicht der mikroskopischen Paläontologie gleichartig analysirter Gebirgsarten der Erde, mit specieller Rucksicht auf den Polycystinen-Mergel von Barbados. Königliche Preussischen Akad. Wissenschaften, Berlin, Abh., Jahre 1875:1-225.

Friend, J. K., and Riedel, W. R., 1967. Cenozoic orosphaerid radiolarians from tropical Pacific sediments. Micropaleontology, 13:217-232.

Goll, R. M., 1968. Classification and phylogeny of Cenozoic Trissocyclidae (Radiolaria) in the Pacific and Caribbean basins. Part 1. J. Paleontol., 42:1409-1432.

Haeckel, E., 1887. Report on the Radiolaria collected by H.M.S. Challenger during the years 1873-76. Report on the Scientific Results of the Voyage of the H.M.S. Challenger. Zoology, 18:1-1803. 
Hathaway, J. C., Schlee, J. S., Poag, C. W., Valentine, P. C., Weed, E.G.A., Bothner, M. H., Kohout, F. A., Manheim, F. T., Schoen, R., Miller, R. E., and Schultz, D. M., 1976. Preliminary summary of the 1976 Atlantic Margin Coring Project of the U.S. Geological Survey. Open-File Rept., 76-844.

Hollister, C. D., and Ewing, J. I., et al., 1972. Init. Repts. DSDP, 11: Washington (U.S. Govt. Printing Office).

Jansa, L. F., Enos, P., Tucholke, B. E., Gradstein, F. M., and Sheridan, R. E., 1979. Mesozoic-Cenozoic sedimentary formations of the North Atlantic basin; Western North Atlantic. In Talwani, M., Hay, W., and Ryan, W.B.F. (Eds.), Deep Drilling Results in the Atlantic Ocean: Continental Margins and Paleoenvironment: Washington (Am. Geophys. Union), 1-57.

Kling, S. A., 1971. Radiolaria, Leg 6 of the Deep Sea Drilling Project. In Fischer, A. G., et al., Init. Repts. DSDP, 6: Washington (U.S. Govt. Printing Office), 1069-1117.

Martin, G. C., 1904. Radiolaria. Miocene: Baltimore (Maryland Geol. Surv.), 447-459.

Moore, T. C., 1971. Radiolaria. In Tracey, J. I., Jr., Sutton, G. H., et al., Init. Repts. DSDP, 8: Washington (U.S. Govt. Printing Office), 727-775.

1972. Mid-Tertiary evolution of the radiolarian genus Calocycletta. Micropaleontology, 18:144-152.

Palmer, A. A., 1986. Miocene radiolarian biostratigraphy, U.S. mid-Atlantic Coastal Plain. Micropaleontology, 32:19-31.

Palmer, A. A., Austin, J. A., Jr., and Schlager, W., 1986. Introduction and Explanatory Notes. In Austin, J. A., Jr., Schlager, W., et al., Proc. ODP, Initial Repts., 101: College Station, TX (Ocean Drilling Program), 5-23.

Riedel, W. R., 1959. Oligocene and lower Miocene Radiolaria in tropical Pacific sediments. Micropaleontology, 5:285-302.

Riedel, W. R., and Sanfilippo, A., 1970. Radiolaria, Leg 4, Deep Sea Drilling Project. In Bader, R. G., Gerard, R. D., et al., Init. Repts. DSDP, 4: Washington (U.S. Govt. Printing Office), 503-575. 1971. Cenozoic Radiolaria from the western tropical Pacific, Leg 7. In Winterer, E. L., Riedel, W. R., et al., Init. Repts. DSDP, 7 (Pt. 1): Washington (U.S. Govt. Printing Office), 1529-1672. 1977. Cainozoic Radiolaria. In Ramsay, A.T.S. (Ed.), Oceanic Micropaleontology: London (Academic Press), 847-912.

1978. Stratigraphy and evolution of tropical Cenozoic radiolarians. Micropaleontology, 24:61-96.

Riggs, S. R., 1984. Paleoceanographic model of Neogene phosphorite deposition, U.S. Atlantic continental margin. Science, 223:123-131.

Sanfilippo, A., Burckle, L. H., Martini, E., and Riedel, W. R., 1973. Radiolarians, diatoms, silicoflagellates and calcareous nannofossils in the Mediterranean Neogene. Micropaleontology, 19:209-234.

Sanfilippo, A., and Riedel, W. R., 1970. Post-Eocene "closed" theoperid radiolarians. Micropaleontology, 16:446-462.

1973. Cenozoic Radiolaria (exclusive of theoperids, artostrobiids and amphipyndacids) from the Gulf of Mexico, Deep Sea Drilling Project Leg 10. In Worzel, J. L., Bryant, W., et al., Init. Repts. DSDP, 10: Washington (U.S. Govt. Printing Office), 475611.

1980. A revised generic and suprageneric classification of the artiscins (Radiolaria). J. Paleontol., 54:1008-1012.

Sanfilippo, A., Westberg-Smith, M. J., and Riedel, W. R., 1985. Cenozoic Radiolaria. In Bolli, H. M., Saunders, J. B., and Perch-Nielsen, K. (Eds.), Plankton Stratigraphy: Cambridge (Cambridge Univ. Press), 631-712.

Sheridan, R. E., Gradstein, F. M., et al., 1983. Init. Repts. DSDP, 76: Washington (U.S. Govt. Printing Office).

Vinassa de Regny, P. E., 1900. Radiolari Miocenici Italiani. R. Accad, Sci. Ist. Bologna, Mem., 5 (8):565-595.

Weaver, F. M., and Dinkelman, M. G., 1978. Cenozoic radiolarians from the Blake Plateau and the Blake-Bahama Basin, DSDP Leg 44. In Benson, W. E., Sheridan, R. E., et al., Init. Repts. DSDP, 44: Washington (U.S. Govt. Printing Office), 865-886.

Date of initial receipt: 21 January 1987

Date of acceptance: 10 July 1987

Ms 101B-129

\section{SPECIES LIST}

Calocycletta costata Riedel

Calocycletta costata Riedel, 1959, p. 296, Pl. 2, Fig. 9. Riedel and Sanfilippo, 1978, p. 66, Pl. 3, Fig. 9.

Calocycletta robusta Moore Calocycletta robusta Moore, 1971, p. 743, Pl. 10, Figs. 5, 6.

Calocycletta serrata Moore Calocycletta serrata Moore, 1972, p. 148, Pl. 2, Figs. 1-3.

Calocycletta virginis (Haeckel) Calocyclas virginis Haeckel, 1887, p. 1381, Pl. 74, Fig. 4. Calocycletta virginis (Haeckel) Moore, 1972, p. 147, Pl. 1, Fig. 4.

Carpocanopsis bramlettei Riedel and Sanfilippo

Carpocanopsis bramlettei Riedel and Sanfilippo, 1971, p. 1597, Pl. 2G, Figs. 8-14; Pl. 8, Fig. 7.

Carpocanopsis cingulata Riedel and Sanfilippo

Carpocanopsis cingulata Riedel and Sanfilippo, 1971, p. 1597, Pl. 2G, Figs. 17-21; Pl. 8, Fig. 8.

Carpocanopsis favosa (Haeckel)

Cycladophora favosa Haeckel, 1887, p. 1380, Pl. 62, Figs. 5, 6.

Carposanopsis favosum (Haeckel), Riedel and Sanfilippo, 1971, p. 1597, Pl. 2G, Figs. 15, 16; Pl. 8, Figs. 9-11.

Carposanopsis favosa (Haeckel) Sanfilippo and Riedel, 1973, p. 531.

Cyclampterium pegetrum Sanfilippo and Riedel

Cyclampterium pegetrum Sanfilippo and Riedel, 1970, p. 546, PI. 2, Figs. 8-10.

Cyrtocapsella cornuta (Haeckel)

Cyrtocapsa (Cyrtocapsella) cornuta Haeckel, 1887, p. 1513, Pl. 78, Fig. 9.

Cyrtocapsella cornuta (Haeckel) Sanfilippo and Riedel, 1970, p. 453, Pl. 1, Figs. 19, 20.

Cyrtocapsella tetrapera (Haeckel)

Cyrtocapsa (Cyrtocapsella) tetrapera Haeckel, 1887, p. 1512, Pl. 78, Fig. 5.

Cyrtocapsella tetrapera (Haeckel) Sanfilippo and Riedel, 1970, p. 453, Pl. 1, Figs. 16-18.

Didymocyrtis laticonus (Riedel)

Cannartus laticonus Riedel, 1959, p. 291, Pl. 1, Fig. 5.

Didymocyrtis laticonus (Riedel), Sanfilippo and Riedel, 1980, p. 1010, Text-Fig. 1, e.

Didymocyrtis mammifera (Haeckel)

Cannartidium mammiferum Haeckel, 1887, p. 375, Pl. 39, Fig. 16.

Cannartus mammiferus (Haeckel), Riedel, 1959, p. 291, Pl. 1, Fig. 4.

Didymocyrtis mammifera (Haeckel), Sanfilippo and Riedel, 1980, p. 1010.

Didymocyrtis prismatica (Haeckel)

Pipettella prismatica Haeckel, 1887, p. 305, Pl. 39, Fig. 6.

Didymocyrtis prismatica (Haeckel), Sanfilippo and Riedel, 1980, p. 1010, Text-Fig. 1, c.

Didymocyrtis violina (Haeckel)

Cannartus violina Haeckel, 1887, p. 358, Pl. 39, Fig. 10. Sanfilippo et al., 1973, Pl. 1, Figs. 11, 12.

Didymocyrtis violina (Haeckel), Sanfilippo and Riedel, 1980, p. 1010.

Dorcadospyris ateuchus (Ehrenberg)

Ceratospyris ateuchus Ehrenberg, 1873, p. 218; 1875, Pl. 21, Fig. 4.

Dorcadospyris ateuchus Ehrenberg), Riedel and Sanfilippo, 1970, p. 523, Pl. 15, Fig. 4.

Dorcadospyris circulis (Haeckel)

Gamospyris circulus Haeckel, 1887, p. 1042, Pl. 83, Fig. 19.

Dorcadospyris circulus (Haeckel), Moore, 1971, p. 739, Pl. 8, Figs. $3,4,5$.

Dorcadospyris dentata Haeckel

Dorcadospyris dentata Haeckel, 1887, p. 1040, Pl. 85, Fig. 6. Riedel and Sanfilippo, 1978, p. 68, Pl. 5, Fig. 4.

Dorcadospyris simplex (Riedel)

Brachiospyris simplex Riedel, 1959, p. 293, Pl. 1, Fig. 10.

Dorcadospyris simplex (Riedel), Riedel and Sanfilippo, 1970, Pl. 15, Fig. 6. Moore, 1971, p. 740, Pl. 10, Figs. 3, 4.

Eucyrtidium diaphanes Sanfilippo and Riedel

Calocyclas coronata Carnevale, 1908, p. 33, Pl. 4, Fig. 24 (not Eucyrtidium coronatum Ehrenberg, 1873).

Eucyrtidium diaphanes Sanfilippo and Riedel, in Sanfilippo et al., 1973 , p. 221, Pl. 5, Figs. 12-14 (new name). 
Site 627

Water depth $1036 \mathrm{~m}$ (corrected)

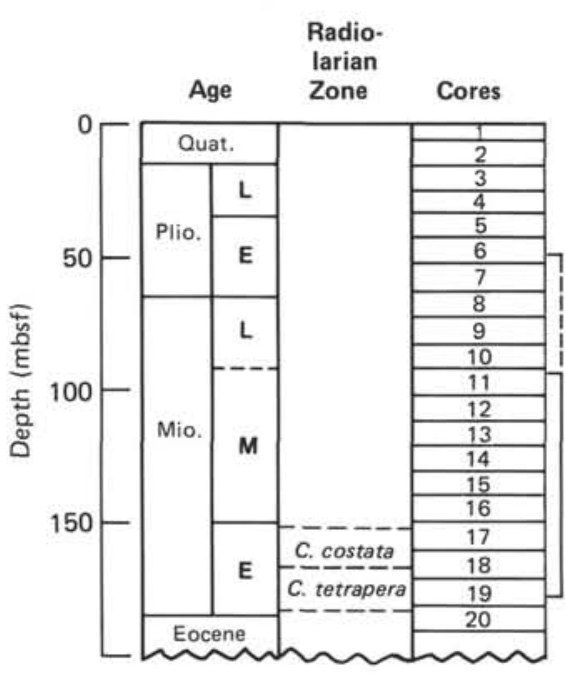

Site 391

Water depth $4974 \mathrm{~m}$ (corrected)

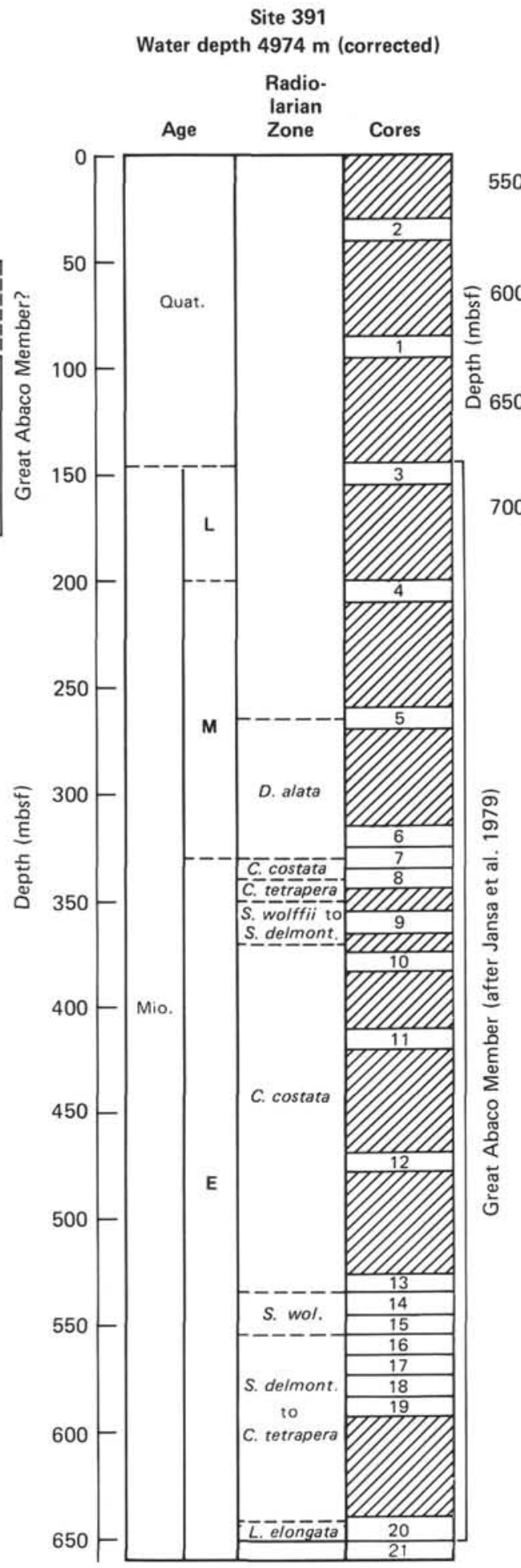

Water depth $4971 \mathrm{~m}$

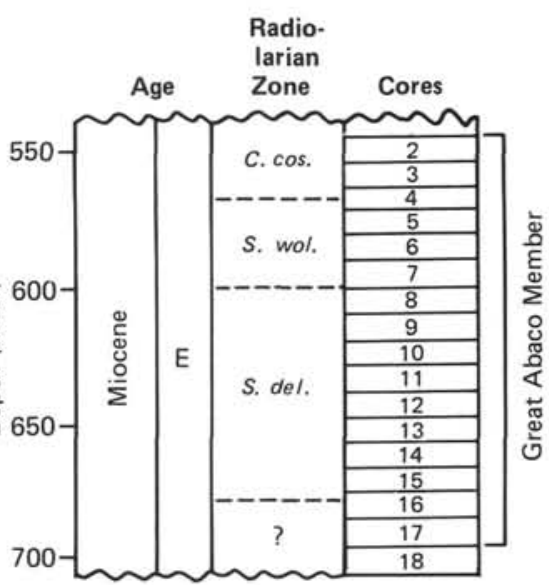

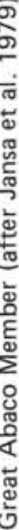

Figure 5. Occurrence of the Great Abaco Member of the Blake Ridge Formation (Jansa et al., 1979) at Sites 627, 391, and 534. Data for Site 627 are from this study; data for Site 391 are from Benson, Sheridan, et al. (1978) and Weaver and Dinkelman (1978); data for Site 534 are from Sheridan, Gradstein, et al. (1983) and from this study.

Liriospyris parkerae Riedel and Sanfilippo

Liriospyris parkerae Riedel and Sanfilippo, 1971, p. 1590, Pl. 2C, Fig. 15; PI. 5, Fig. 4.

Liriospyris stauropora (Haeckel)

Trissocyclus stauropora Haeckel, 1887, p. 987, Pl. 83, Fig. 5.
Liriospyris stauropora (Haeckel), Goll, 1968, p. 1431, Pl. 75, Figs. $1-3,7$, Text-Fig. 9. Lithocyclia angusta (Reidel)

Trigonactura angusta Riedel, 1959, p. 292, Pl. 1, Fig. 6.

Lithocyclia angusta (Riedel), Riedel and Sanfilippo, 1970, p. 522, 
Pl. 13, Figs. 1, 2; Sanfilippo, Westberg-Smith and Riedel, 1985, p. 653 , Fig. $7.3 \mathrm{c}$.

Lithopera renzae Sanfilippo and Riedel

Lithopera (Lithopera) renzae Sanfilippo and Riedel, 1970, p. 454, Pl. 1, Figs. 21-23, 27.

Lithopera renzae Sanfilippo and Riedel, Riedel and Sanfilippo, 1978, p. 70, Pl. 6, Fig. 11.

Lychnocanoma elongata (Vinassa)

Tetrahedrina elongata Vinassa, 1900, p. 243, Pl. 2, Fig. 31.

Lychnocanoma elongata (Vinassa) Sanfilippo and Riedel in Sanfilippo et al., 1973, p. 221, Pl. 5, Figs. 19, 20.

Lychnocanoma trifolium (Riedel and Sanfilippo)

Lychnocanium trifolium Riedel and Sanfilippo, 1971, p. 1595, Pl. 3B, Fig. 12; Pl. 8, Figs. 2, 3.

Lychnocanoma trifolium (Riedel and Sanfilippo) by implication in Sanfilippo et al., 1973, p. 221.

Oradapis spongiosa Friend and Riedel

Oradapis spongiosa Friend and Riedel, 1967, p. 222-223, Pl. 1, Figs. 7-10.

Oroscena carolae Friend and Riedel

Oroscena carolae Friend and Riedel, 1967, p. 225-226, Pl. 2, Figs. 1, 2.
Oroscena gegenbauri Haeckel

Oroscena gegenbauri Haeckel, 1887, p. 1597-1598, Pl. 106, Fig. 4. Friend and Riedel, 1967, p. 225, Pl. 2, Figs. 7, 8.

Oropagis dolium Friend and Riedel

Oropagis dolium Friend and Riedel, 1967, p. 226-228, Pl. 3, Figs. 4-10.

Spongasteriscus marylandicus Martin

Spongasteriscus marylandicus Martin, 1904, p. 453, Pl. 130, Fig. 10. Palmer, 1986, p. 28, Pl. 1, Fig. 2.

Stichocorys delmontensis (Campbell and Clark)

Eucyrtidium delmontense Campbell and Clark, 1944, p. 56, Pl. 7, Figs. 19, 20.

Stichocorys delmontensis (Campbell and Clark), Sanfilippo and Riedel 1970, p. 451, Pl. 1, Fig. 9.

Stichocorys wolffii Haeckel

Stichocorys wolffii Haeckel, 1887, p. 1479, Pl. 80, Fig. 10.

Tepka perforata Sanfilippo and Riedel

Tepka perforata Sanfilippo and Riedel, in Sanfilippo et al., 1973, p. 228-230, Pl. 6, Figs. 18-20.

Theocorys spongoconum Kling

Theocorys spongoconum Kling, 1971, p. 1087, Pl. 5, Fig. 6.

Tristylospyris triceros (Ehrenberg)

Ceratospyris triceros Ehrenberg, 1873, p. 220; 1875, Pl. 21, Fig. 5. Tristylospyris triceros (Ehrenberg), Haeckel, 1887, p. 1033. 


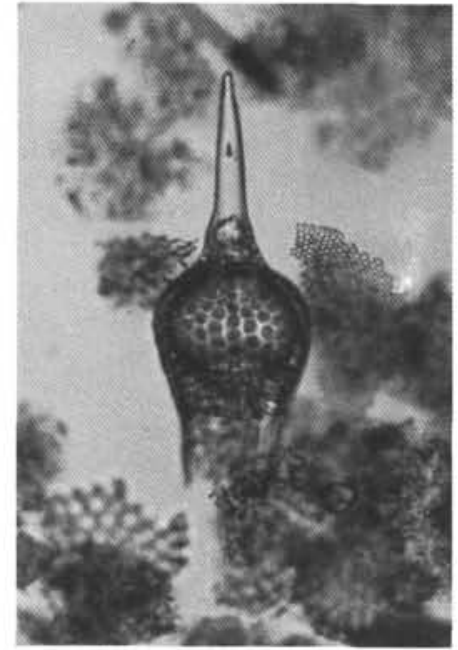

1

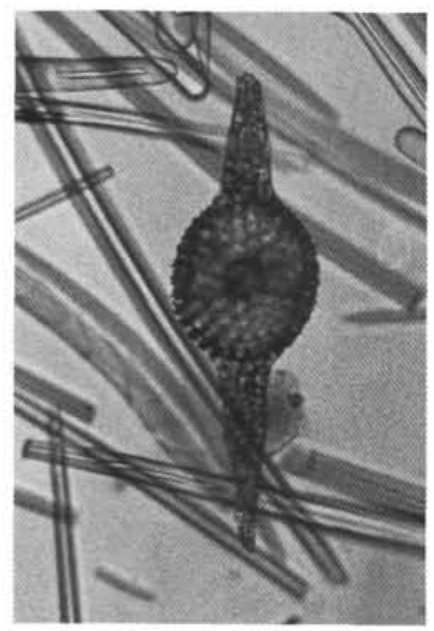

4

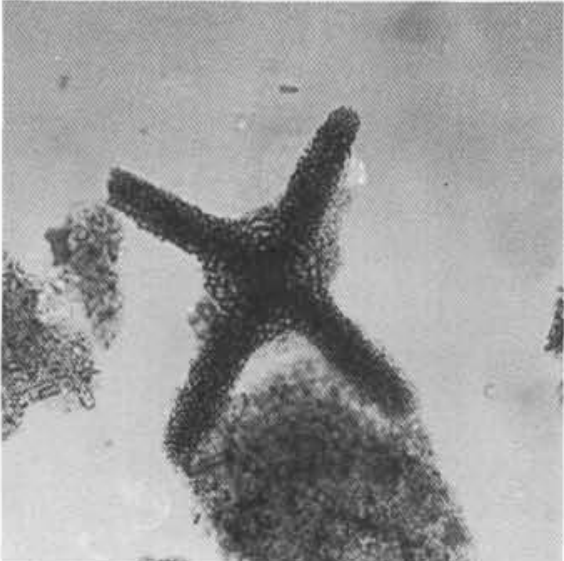

2

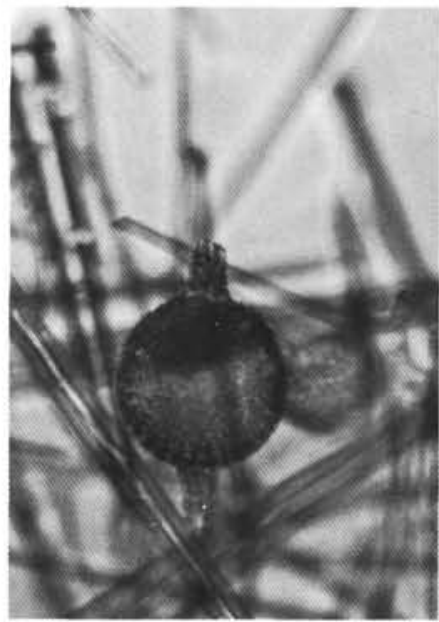

5

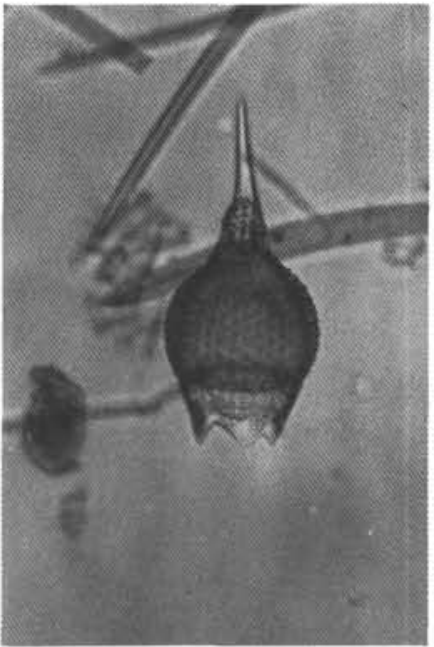

3

$100 \mu \mathrm{m}$

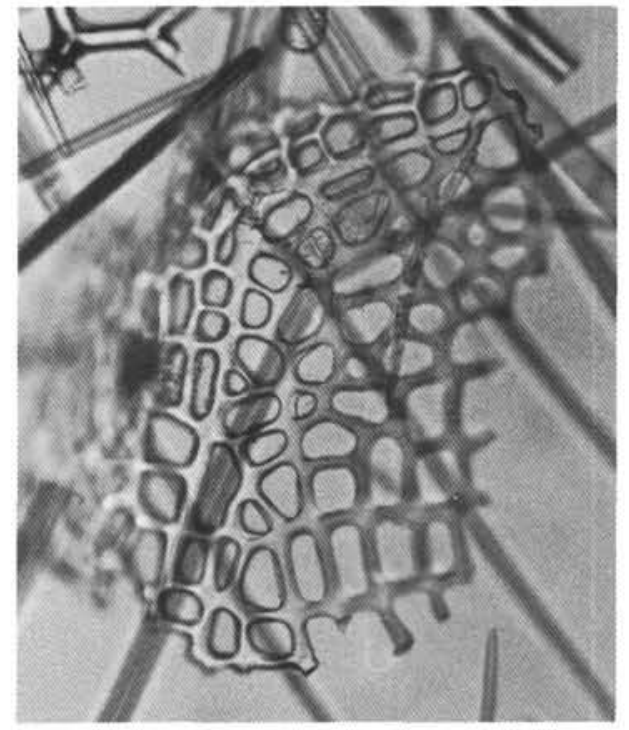

6

Plate 1. Miocene and Oligocene radiolarians. 1. Calocycletta costata (Sample 76-534A-4-2, 80-82 cm). 2. Spongasteriscus marylandicus (Sample 76-534A-7-3, 74-76 cm). 3. Calocycletta serrata (Section 101-627B-19X, CC). 4. Didymocyrtis prismatica, early Miocene form (Section 101627B-19X, CC). 5. Didymocyrtis prismatica, late Oligocene from (Sample 101-628A-19X-1, 50-52 cm). 6. Orosphaerid(?) fragment (Sample 101$628 \mathrm{~A}-19 \mathrm{X}-1,50-52 \mathrm{~cm})$. 


\section{A. A. PALMER}

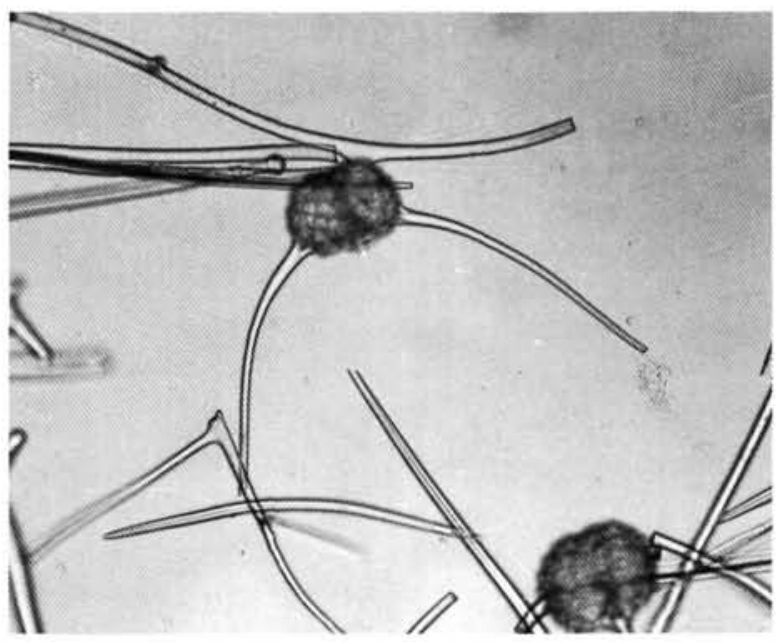

1

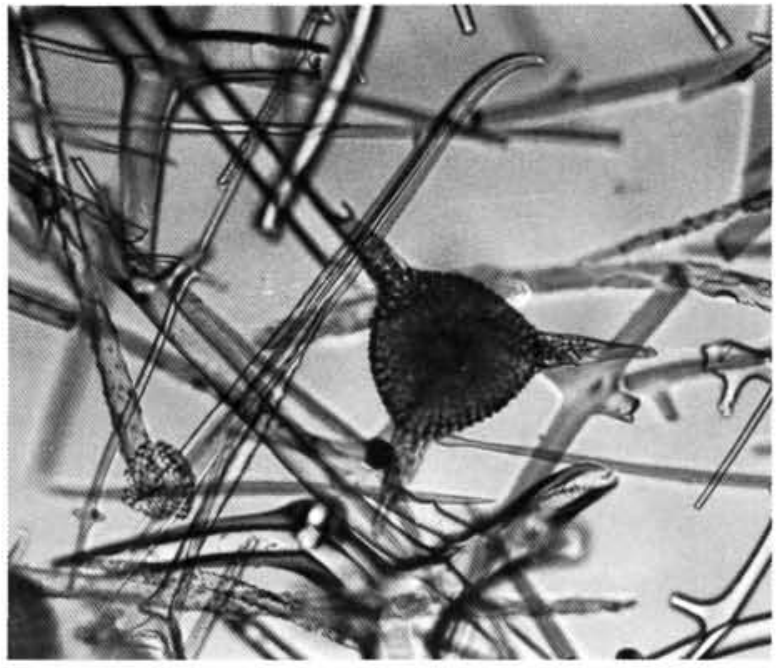

3

$100 \mu \mathrm{m}$

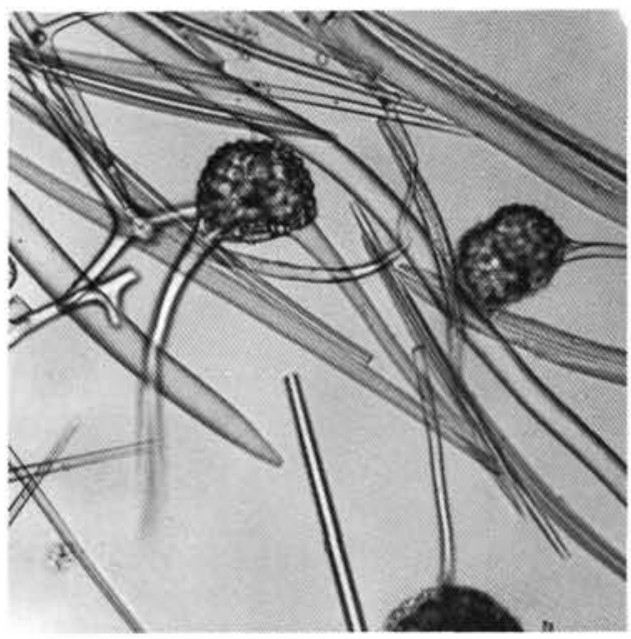

2

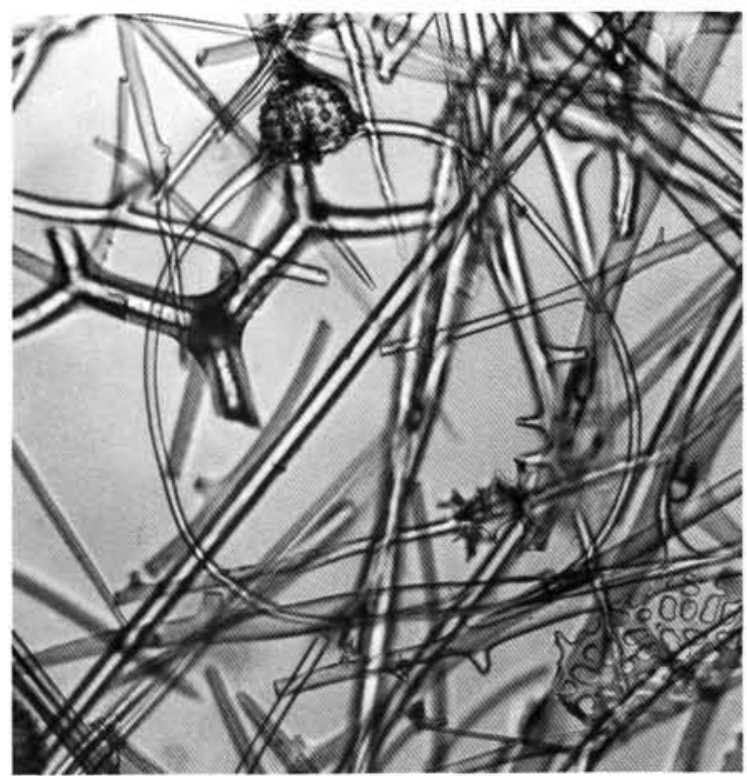

4

Plate 2. Oligocene radiolarians. 1. Dorcadospyris simplex (Sample 101-628A-19-1, 50-52 cm). 2. Dorcadospyris ateuchus (Sample 101-628A19H-1, 50-52 cm). 3. Lithocyclia angusta, "late form," with bladed spines at termination of spongy arms (Sanfilippo, Westberg-Smith, and Riedel, 1985) (Sample 101-628A-19H-1, 50-52 cm). 4. Dorcadospyris circulis (Sample 101-628A-19H-1, 50-52 cm). 